ALEKSANDRA NEŠIĆ, Ph.D. Candidate ${ }^{1}$

(Corresponding author)

E-mail: aleksandradjordj@gmail.com

OLJA ČOKORILO, Ph.D. ${ }^{1}$

E-mail: o.cokorilo@sf.bg.ac.rs

SANJA STEINER,Ph.D. ${ }^{2}$

E-mail: ssteiner@fpz.hr

1 University of Belgrade,

Faculty of Transport and Traffic Engineering

Vojvode Stepe 305, 11000 Belgrade, Serbia

2 University of Zagreb,

Faculty of Transport and Traffic Sciences

Vukelićeva 4, 10000 Zagreb, Croatia
Transport in Emergency Situations

Preliminary Communication

Submitted: 9 Feb. 2017

Accepted: 11 Oct. 2017

\title{
AIRCRAFT REPAIR AND WITHDRAWAL COSTS GENERATED BY BIRD COLLISION WITH THE WINDSHIELD
}

\begin{abstract}
According to available data released by the European Aviation Safety Agency (EASA) in the period from 1990 to 2007, more than 94,743 collisions with birds occurred on the territory of US, UK and Canada. In some parts of the world bird population is significantly growing. Also, the number of aircraft operations has increased in recent decades, and more importantly, their increase is expected in the future as well. In these conditions, the number of aircraft collisions with birds is expected to grow. Bird strikes are affecting safety and also generate additional costs in air traffic. This paper will show what type of bird strike costs exist with focus on repair and withdrawal of bird strike costs. Repair and withdrawal costs due to bird strike are specific because they could vary from insignificant amount up to millions of dollars and because of its unpredictability.
\end{abstract}

\section{KEY WORDS}

bird strike; safety; repair costs; aircraft withdrawal;

\section{INTRODUCTION}

Wildlife strikes are everyday events in air transport and could have multiple and various effects on flight. The most common are bird strike events, while collision with mammals, bats, reptiles or other animals are less common. For instance, from 1990 to 2013 on the territory of USA only, there were 142,603 wildlife strikes, out of which 138,257 strikes were collisions with birds [1]. Recognizing the principles of sustainability, the projection of air traffic development needs to evaluate both the social and economic benefits of the aviation industry, and the external costs caused by air traffic [2].

Severity of bird strikes depends on factors like impact force, part of aircraft that suffered the strike and the material of which the impacted part is composed, flight phase, and aircraft/engine performances.
According to [3] seven percent of the bird strikes resulted in minor damage, while three percent resulted in serious damage to the aircraft. Except making damage bird strikes may cause delay or cancelation of flight, withdrawal from traffic for inspection and damage repair, crew or passengers injuring, extra costs and customers' frustration.

The distinctiveness of bird strike costs is its complexity and difficult separation from other costs in air traffic industry. Bird strike could have multiple effects and costs of such event will be calculated as sum of costs of single effects. Beside repair costs, delay/cancelation costs take special place because of their possible effect on succeeding flights. No matter what the cause of flight delays are, they are very expensive for the aviation industry. According to Institut du Transport Aérien (ITA) the average unit cost per minute of delay varies from 39.4 euro to 48.6 euro for the airlines.

Damage and withdrawal costs are defined by extent of damage and Maintenance Repair and Overhaul (MRO) company which services the aircraft. Extent of damage will mostly depend on the size of birds and number of birds that participated in the collision. EASA stated that from 1999 to 2008 the majority of birds involved were flocks of large birds (45\%) followed by strikes by single large birds (31\%) [4]. Parts that are the most reported ones as damaged in bird strikes are the most exposed aircraft parts: engines, wings and windshields. In this paper focus will be on the costs of windshield damage considering that windshield is one of the most endangered part of the aircraft in the bird strike events.

\section{BIRD STRIKE EFFECT ON FLIGHT}

Lately, birds strike events have been in the spotlight because of their influence on flight safety and costs in aviation industry. What effect strike will have 
depends on many factors, one of them being which part of aircraft suffered impact. Jet engines are particularly vulnerable during the take-off phase when the engine is turning at a very high speed and the aircraft is at a low altitude where birds are more commonly found [5]. Because of exposure to strike, engines, wings and windshields are the most reported parts that suffer damages after bird strike, please see Figure 1.

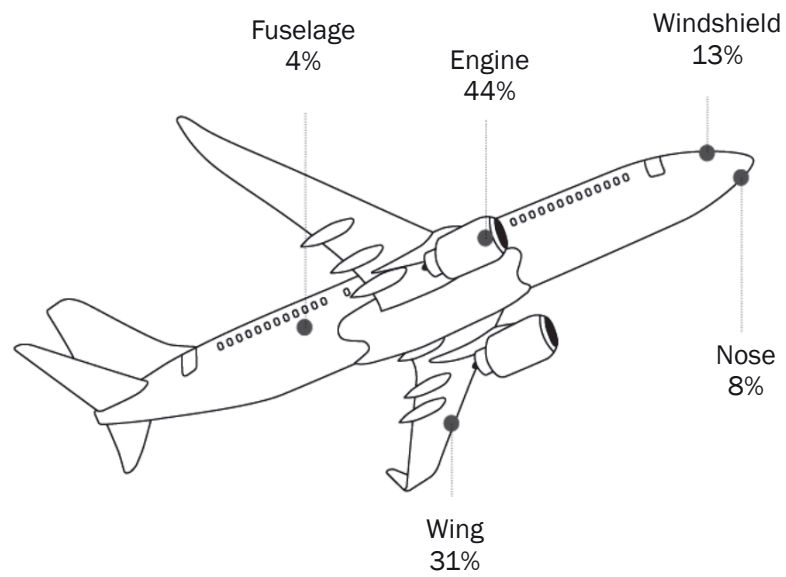

Figure 1 - Engines and wings - the most common locations of bird strike [6]

Effect on flight based on the part that suffered impact:

- Engine: fire, power decrease, complete loss of power, difficulties in manoeuvring;

- Wing: damage of electrical or hydraulic system, increasing drag due to losing aero dynamical shape;

- Windshield: cabin decompression, decreasing visibility, injured pilot;

- Gear and tail: manoeuvrability and stability issues. During collision with birds aircraft absorbs energy that is proportional to the birds mass and square of relative speed of bird's movement in relation to the aircraft. Impact energy, and therefore the damage to the aircraft, will increase with the increase in mass of birds and speed. Besides, energy will depend on the angle at which the collision occurred, and if there is a bird strike with fan motor, the energy of impact will depend on the engine speed and the exact location of impact.

Depending on damage caused by strike, certain cases require aircraft withdrawal from traffic for servicing, and often cause flight delays and cancellations. According to International Civil Aviation Organization (ICAO) based on 31,767 bird strikes in the period from 2001 to 2007 in $90 \%$ of cases (28,576 strikes) there was no effect on flight. In other $10 \%$ of cases (3,191 strikes) strike affected the flight: aborted takeoff (27\%), precautionary landing (46\%), engine failure (3\%) and other effects (24\%) [7].

\section{CLASSIFICATION OF THE COSTS CAUSED BY BIRD STRIKES}

A huge problem in this field is the precise determination of costs resulting from the collision of aircraft with birds because not every collision has been reported, but this does not mean that if it was not reported that it did not cause any damage to the aircraft and therefore additional costs.

All these effects of aircraft-bird collisions could cause delay and withdrawal of aircraft from traffic due to the repair of damaged parts. Also, one bird strike may have multiple effects, not just one. The characteristics of strike are different in case of strike with individual bird or with a flock of birds.

One of the effects of the collision of aircraft with birds are certainly additional costs. The most important among them are the cost of repairing damage caused by impact and costs of delays or cancellation of flight. According to a study conducted by Airbus every fifth bird strike will damages the aircraft and two out of three strikes will lead to delays. The UK National wildlife management centre estimates that the annual costs of aircraft-bird collisions are at least 1.2 billion dollars (888 million euro) [8].

According to the Federal Aviation Administration (FAA) from 1990 to 2008 on the territory of the US collisions with birds caused death of 16 people, 49 aircraft were destroyed, the estimated costs were 308.3 million dollars, and aircraft were grounded for 393,521h [9].

All bird strike-related costs in air traffic could be generally selected in the following groups:

- Bird strike prevention costs;

- Flight delay/cancellation due to bird strike;

- Costs of lost demand;

- Damage repair costs.

\subsection{Bird strike prevention costs}

Bird strike prevention costs are complex and reach all segments of air traffic. This type of costs consists of equipment costs for bird dispersal and detection, training staff for handling equipment, costs of engaging staff to work on preventing bird strikes, modifications in the vicinity of the airport in order to make area unattractive for birds. Bird strike prevention costs also include costs of training pilots and air traffic controllers on how to handle these cases. It is difficult to estimate the costs of research projects for preventing bird strikes because these projects could be driven by different education or non-profit institutions.

\subsection{Flight delay/cancellation due to bird strikes}

The cost of delay or cancellation of flight may be primary or secondary: primary, if the impact occurred during the current flight, or secondary, if impact 
occurred during previous flight, which was reflected in subsequent flights. Per Central Office for Delay Analysis (CODA) the share of reactionary out of all delays account for about 40 percent of total generated delay minutes [10]. ITA research states that the costs impact of a primary delay is higher than the cost impact of reactionary delay. Each minute of primary delay generates 2/3 minutes of reactionary delay, the total airline unit cost per minute of Air Traffic Flow Management(ATFM) delay ranges from around 59 euro to 85 euro for each minute of primary delay [11]. In case of cargo transport there are also penalties that air companies need to pay for late delivery of cargo. It is estimated that bird strikes cost the aviation industry more than 1 billion euro per year, as result from direct damage to aircraft (which account for $12 \%$ of the cost) and from delays and their associated costs following bird strikes per EASA.

The total delay impact (TDI) project conducted by the FAA showed that the costs which were result of delays or cancellations of flight only in the US amounted to 32.9 billion dollars in 2007 only. The project calculated total delay/cancellation costs as the sum of the costs of carrier aviation, passenger costs, costs of lost demand and costs indirect impact on the economy of the country.

\subsection{Costs of lost demand}

Costs of lost demand are costs based on loss of passengers who due to delays / cancellation will avoid this type of transport. Bad image and loss of passenger confidence will lead to loss of revenue and extra expenses incurred to restore the "good name" [12]. The costs of lost demand are complex because there are too many factors that contribute to decreasing demand, like economic situation, terroristic activities or expansion of other transport modes.

\subsection{Damage repair costs}

Damage repair costs depend on the extent of damage, part of aircraft that suffered impact, aircraft manufacturer, model of aircraft (or engine if engine is damaged), maintenance company work policy and its contract with the air traffic company. Repair costs could vary from insignificant amount to a few million dollars. Table 1 shows the number of bird strikes and the extent of damage as result of bird strikes.

Collisions with birds may cause different types of costs in aviation; costs of aircraft withdrawal from transport in order to perform inspection and repair damage caused by the impact take a special place among them. These costs are best explained through annual/daily usage. Aircraft utilization is the active time of aircraft assets use per unit of time. An average for in-service fleet, but it could also include selected parked fleet expressed in flight hours per day [14].

\section{COSTS OF DAMAGE REPAIR AND AIRCRAFT BEING OUT OF SERVICE AFTER BIRD STRIKE TO WINDSHIELD}

Cost data are defined for air carrier and general aviation aircraft as variable or fixed. Variable costs change in proportion to aircraft usage, and include fuel and oil, maintenance and crew costs [15]. Scheduled and unscheduled aircraft maintenance is an important part of airlines costs and consists of several elements. According to ICAO from 2001 to 2007 there were 236 bird strikes that damaged the aircraft windshields. In this kind of cases it required servicing the damaged part which means removing aircraft from traffic, inspecting the extent of damage, replacing the damaged component, testing and returning to normal operation. Withdrawing aircraft from traffic and servicing the windshield can be calculated as sum of direct operating costs (DOC) which increase due to aircraft being out of service, costs of material for damage repair and engaging maintenance staff. The direct operating costs will have major influence on aircraft withdrawal costs; here, three cases depending on the presumed DOC value will be discussed (Tables 2-4, Figures 2-5). In all three cases DOC increase due to aircraft being out of service will be based on [16]. The material price and man-hour depend on particular MRO company but in this case the presumed values will be: windshield repair cost - $\$ 1,900$, per side; windshield replacement cost - \$22,000, per side; replacement time per side 100-120 hours per side; repair time - 5 hours per side; maintenance employees man-hour: $30 \$$ /hours

Table 1 - The number of civil aircraft with reported damage resulting from wildlife strikes, US, 1990-2014 [13]

\begin{tabular}{|c|c|c||}
\hline Type of damage & From 1990 to 2014 & \% of total \\
\hline \hline None & 96,287 & 64 \\
\hline Unknown & 41,998 & 9 \\
\hline Damage & 12,982 & 5 \\
\hline Minor & 6,964 & 2 \\
\hline Uncertain & 2,647 & 2 \\
\hline Substantial & 3,334 & $<1$ \\
\hline Destroyed & 37 & \\
\hline
\end{tabular}


Scenario 1: $D 0 C=8,000 \$$

Table 2 - Costs of windshield replacement when replacement took 100 or 120 hours if DOC is 8,000\$

\begin{tabular}{||c|c|c|c|c|c|c|c||}
\hline $\begin{array}{c}\text { Number } \\
\text { of weeks } \\
\text { out of service }\end{array}$ & $\begin{array}{c}\text { DOC } \\
\text { increase } \\
{[\%]}\end{array}$ & $\begin{array}{c}\text { DOC } \\
\text { increase }\end{array}$ & Material & $\begin{array}{c}\text { Maintenance } \\
\text { staff working } \\
\text { 100 hours }\end{array}$ & $\begin{array}{c}\text { Maintenance } \\
\text { staff working } \\
120 \text { hours }\end{array}$ & $\begin{array}{c}\text { Total } \\
\text { (if replacement } \\
\text { took 100 hours) }\end{array}$ & $\begin{array}{c}\text { Total } \\
\text { (if replacement } \\
\text { took 120 hours) }\end{array}$ \\
\hline \hline 0 & 0 & 0 & 22,000 & 3,000 & 3,600 & 25,000 & 25,600 \\
\hline 1.5 & 3.7 & 296 & 22,000 & 3,000 & 3,600 & 25,296 & 25,896 \\
\hline 2 & 4.22 & 337.6 & 22,000 & 3,000 & 3,600 & $25,337.6$ & $25,937.6$ \\
\hline 2.5 & 4.77 & 381.6 & 22,000 & 3,000 & 3,600 & $25,381.6$ & $25,981.6$ \\
\hline 3 & 5.33 & 426.4 & 22,000 & 3,000 & 3,600 & $25,426.4$ & $26,026.4$ \\
\hline 3.5 & 5.9 & 472 & 22,000 & 3,000 & 3,600 & 25,472 & 26,072 \\
\hline 4 & 6.49 & 519.2 & 22,000 & 3,000 & 3,600 & $25,519.2$ & $26,119.2$ \\
\hline 4.5 & 7.06 & 564.8 & 22,000 & 3,000 & 3,600 & $25,564.8$ & $26,164.8$ \\
\hline 5 & 7.7 & 616 & 22,000 & 3,000 & 3,600 & 25,616 & 26,216 \\
\hline 5.5 & 8.32 & 665.6 & 22,000 & 3,000 & 3,600 & $25,665.6$ & $26,265.6$ \\
\hline 6 & 8.96 & 716.8 & 22,000 & 3,000 & 3,600 & $25,716.8$ & $26,316.8$ \\
\hline 6.5 & 9.62 & 769.6 & 22,000 & 3,000 & 3,600 & $25,769.6$ & $26,369.6$ \\
\hline 7 & 10.29 & 823.2 & 22,000 & 3,000 & 3,600 & $25,823.2$ & $26,423.2$ \\
\hline 7.5 & 10.98 & 878.4 & 22,000 & 3,000 & 3,600 & $25,878.4$ & $26,478.4$ \\
\hline 8 & 11.69 & 935.2 & 22,000 & 3,000 & 3,600 & $25,935.2$ & $26,535.2$ \\
\hline
\end{tabular}

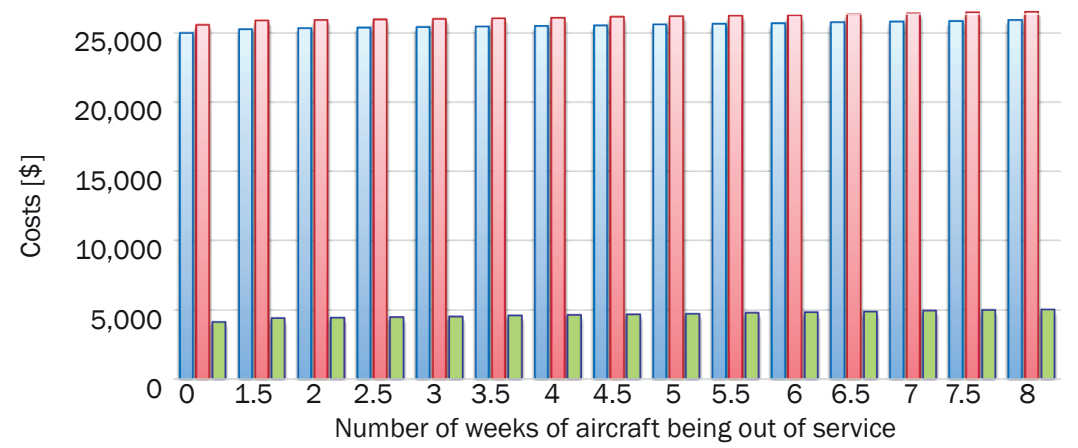

One side replacement $(100 \mathrm{~h}) \quad$ One side replacement $(120 \mathrm{~h}) \quad$ Two sides repair $(10 \mathrm{~h})$

Figure 2 - Number of weeks of aircraft being out of service and withdrawal costs, $D O C=8,000 \$$

Scenario 2: $D O C=9,000 \$$

Table 3 - Costs of windshield replacement when replacement took 100 or 120 hours if DOC is 9,000\$

\begin{tabular}{||c|c|c|c|c|c|c|c||}
\hline $\begin{array}{c}\text { Number } \\
\text { of weeks } \\
\text { out of service }\end{array}$ & $\begin{array}{c}\text { DOC } \\
\text { increase } \\
{[\%]}\end{array}$ & $\begin{array}{c}\text { DOC } \\
\text { increase }\end{array}$ & Material & $\begin{array}{c}\text { Maintenance } \\
\text { staff working } \\
100 \text { hours }\end{array}$ & $\begin{array}{c}\text { Maintenance } \\
\text { staff working } \\
120 \text { hours }\end{array}$ & $\begin{array}{c}\text { Total } \\
\text { (if replacement } \\
\text { took 100 hours) }\end{array}$ & $\begin{array}{c}\text { Total } \\
\text { (if replacement } \\
\text { took 120 hours) }\end{array}$ \\
\hline \hline 0 & 0 & 0 & 22,000 & 3,000 & 3,600 & 25,000 & 25,600 \\
\hline 1.5 & 3.7 & 333 & 22,000 & 3,000 & 3,600 & 25,333 & 25,933 \\
\hline 2 & 4.22 & 379.8 & 22,000 & 3,000 & 3,600 & $25,379.8$ & $25,979.8$ \\
\hline 2.5 & 4.77 & 429.3 & 22,000 & 3,000 & 3,600 & $25,429.3$ & $26,029.3$ \\
\hline 3 & 5.33 & 479.7 & 22,000 & 3,000 & 3,600 & $25,479.7$ & $26,079.7$ \\
\hline 3.5 & 5.9 & 531 & 22,000 & 3,000 & 3,600 & 25,531 & 26,131 \\
\hline 4 & 6.49 & 584.1 & 22,000 & 3,000 & 3,600 & $25,584.1$ & $26,184.1$ \\
\hline 4.5 & 7.06 & 635.4 & 22,000 & 3,000 & 3,600 & $25,635.4$ & $26,235.4$ \\
\hline 5 & 7.7 & 693 & 22,000 & 3,000 & 3,600 & 25,693 & 26,293 \\
\hline 5.5 & 8.32 & 748.8 & 22,000 & 3,000 & 3,600 & $25,748.8$ & $26,348.8$ \\
\hline 6 & 8.96 & 806.4 & 22,000 & 3,000 & 3,600 & $25,806.4$ & $26,406.4$ \\
\hline 6.5 & 9.62 & 865.8 & 22,000 & 3,000 & 3,600 & $25,865.8$ & $26,465.8$ \\
\hline 7 & 10.29 & 926.1 & 22,000 & 3,000 & 3,600 & $25,926.1$ & $26,526.1$ \\
\hline 7.5 & 10.98 & 988.2 & 22,000 & 3,000 & 3,600 & $25,988.2$ & $26,588.2$ \\
\hline 8 & 11.69 & $1,052.1$ & 22,000 & 3,000 & 3,600 & $26,052.1$ & $26,652.1$ \\
\hline
\end{tabular}




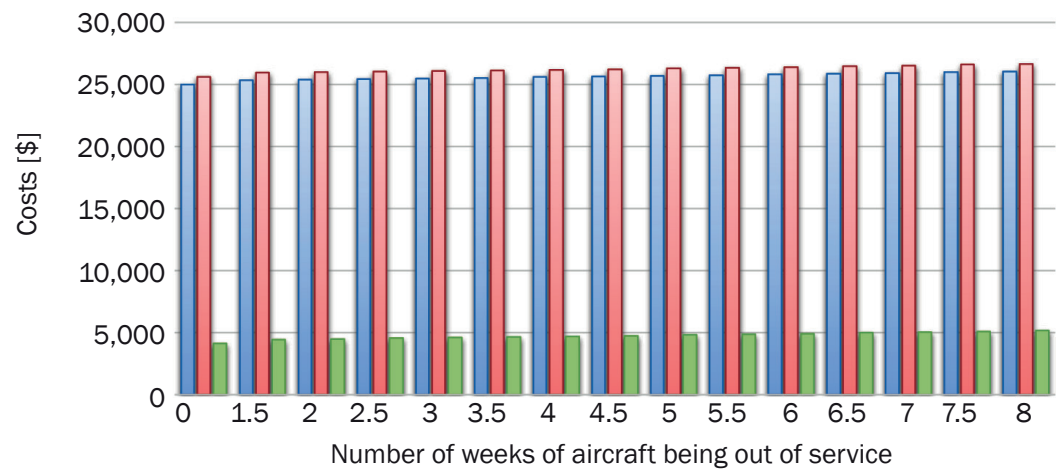

$\square$ One side replacement $(100 \mathrm{~h}) \quad \square$ One side replacement $(120 \mathrm{~h}) \quad \square$ Two sides repair $(10 \mathrm{~h})$

Figure 3 - Number of weeks of aircraft being out of service and withdrawal costs, $D O C=9,000 \$$

Scenario 3: $D O C=10,000 \$$

Table 4 - Costs of windshield replacement when replacement took 100 or 120 hours if DOC is $10,000 \$$

\begin{tabular}{|c|c|c|c|c|c|c|c||}
\hline \hline $\begin{array}{c}\text { Number } \\
\text { of weeks } \\
\text { out of service }\end{array}$ & $\begin{array}{c}\text { DOC } \\
\text { increase } \\
{[\%]}\end{array}$ & $\begin{array}{c}\text { DOC } \\
\text { increase }\end{array}$ & Material & $\begin{array}{c}\text { Maintenance } \\
\text { staff working } \\
100 \text { hours }\end{array}$ & $\begin{array}{c}\text { Maintenance } \\
\text { staff working } \\
120 \text { hours }\end{array}$ & $\begin{array}{c}\text { Total } \\
\text { (if replacement } \\
\text { took 100 hours) }\end{array}$ & $\begin{array}{c}\text { Total } \\
\text { (if replacement } \\
\text { took 120 hours) }\end{array}$ \\
\hline \hline 0 & 0 & 0 & 22,000 & 3,000 & 3,600 & 25,000 & 25,600 \\
\hline 1.5 & 3.7 & 1,370 & 22,000 & 3,000 & 3,600 & 26,370 & 26,970 \\
\hline 2 & 4.22 & 1,422 & 22,000 & 3,000 & 3,600 & 26,422 & 27,022 \\
\hline 2.5 & 4.77 & 1,477 & 22,000 & 3,000 & 3,600 & 26,477 & 27,077 \\
\hline 3 & 5.33 & 1,533 & 22,000 & 3,000 & 3,600 & 26,533 & 27,133 \\
\hline 3.5 & 5.9 & 1,590 & 22,000 & 3,000 & 3,600 & 26,590 & 27,190 \\
\hline 4 & 6.49 & 1,649 & 22,000 & 3,000 & 3,600 & 26,649 & 27,249 \\
\hline 4.5 & 7.06 & 1,706 & 22,000 & 3,000 & 3,600 & 26,706 & 27,306 \\
\hline 5 & 7.7 & 1,770 & 22,000 & 3,000 & 3,600 & 26,770 & 27,370 \\
\hline 5.5 & 8.32 & 1,832 & 22,000 & 3,000 & 3,600 & 26,832 & 27,432 \\
\hline 6 & 8.96 & 1,896 & 22,000 & 3,000 & 3,600 & 26,896 & 27,496 \\
\hline 6.5 & 9.62 & 1,962 & 22,000 & 3,000 & 3,600 & 26,962 & 27,562 \\
\hline 7 & 10.29 & 2,029 & 22,000 & 3,000 & 3,600 & 27,029 & 27,629 \\
\hline 7.5 & 10.98 & 2,098 & 22,000 & 3,000 & 3,600 & 27,098 & 27,698 \\
\hline 8 & 11.69 & 2,169 & 22,000 & 3,000 & 3,600 & 27,169 & 27,769 \\
\hline
\end{tabular}

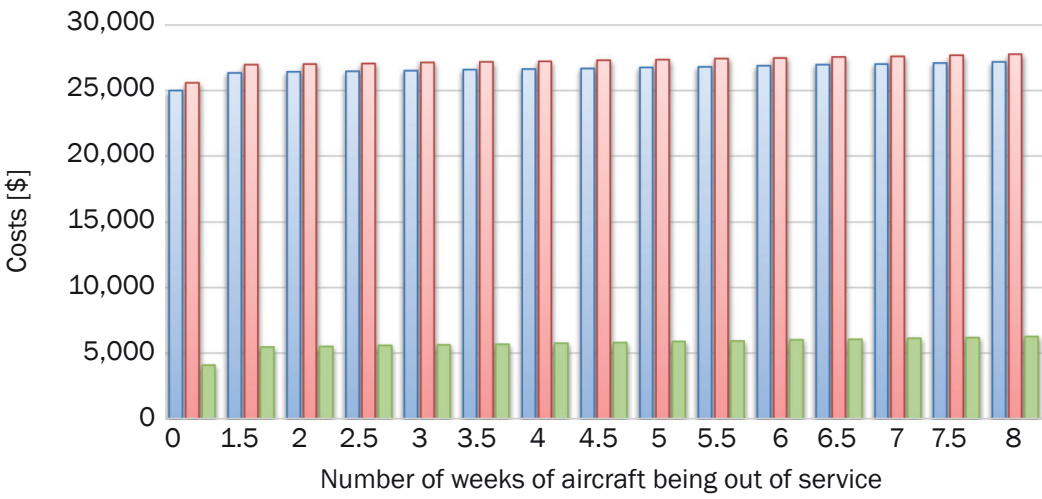

- One side replacement $(100 \mathrm{~h}) \quad$ One side replacement $(120 \mathrm{~h}) \quad$ Two sides repair $(10 \mathrm{~h})$

Figure 4 - Number of weeks of aircraft being out of service and withdrawal costs, $D O C=10,000 \$$ 


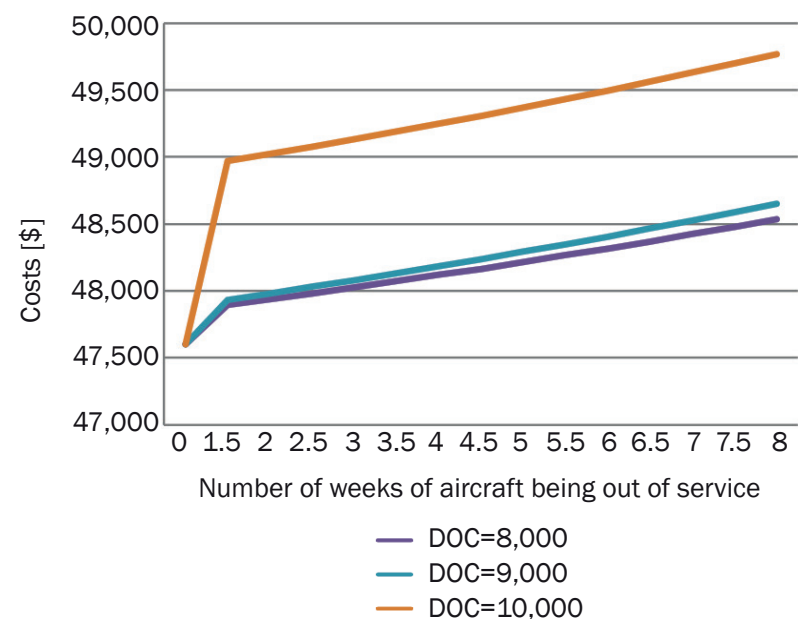

Figure 5 - Number of weeks of aircraft being out of service and repair/withdrawal costs in case of two sides windshield replacement

\section{CONCLUSION}

In an environment with great competition, difficult economic conditions and high operation costs, air traffic companies have to carefully analyse and eliminate costs that are not necessary. Aircraft collisions with birds are risks that cannot be completely eliminated, but it is possible to successfully manage this hazard. The history of recorded accidents worldwide shows that take-off and landing are the most dangerous flight phases. According to statistical data take-off and landing phase have been the most probable situations for initiating accidents [17]. Considering that the majority of strikes happens in the vicinity of airports the habitat management is necessary whose aim should be making the airport area unattractive for birds. Also, for managing this hazard modern technical devices have been used nowadays; different models of radars are being used for tracking birds as well as numerous devices for dispersing birds. Even if an airport is evaluated as bird strike safe area or the applied measures gave the desired results, this is not a point where the process ends; constant monitoring and regular re-evaluations are required to make sure that there are no new circumstances and that the airport maintains safe traffic [18]. Besides, aircraft manufacturers need to examine and test aircraft and engine impact resistance and aircraft ability to continue flight after suffering impact. Collisions with birds carry a big security risk, and as result, such events between 1912 and 2008 claimed lives of 242 persons, and the annual costs exceeded 1.2 billion dollars. The paper has shown how DOC increase influences the bird strike costs and also how time spent out of traffic due to bird strike influences the increase in costs. As commonly reported, the damaged part in bird strike, the wind shield was discussed in two cases: first, when it was possible to repair the damage and second, when repair was not possible and replacement was required. Also, it is shown in which way the price of material and working hours of maintenance staff affect costs. Because of its unpredictability and extra costs, bird strikes require great attention due to the expected increase in air traffic, but also an increase in bird populations in almost all parts of the world.

\section{Sc. ALEKSANDRA NEŠIĆ ${ }^{1}$}

E-mail: aleksandradjordj@gmail.com

Dr. Sc. OLJA ČOKORILO ${ }^{1}$

E-mail: o.cokorilo@sf.bg.ac.rs

Dr. sc. SANJA STEINER ${ }^{2}$

E-mail: ssteiner@fpz.hr

1 Univerzitet u Beogradu, Saobraćajni Fakultet Vojvode Stepe 305, 11000 Beograd, Srbija

2 Sveučilište u Zagrebu, Fakultet prometnih znanosti Vukelićeva 4, 10000 Zagreb, Hrvatska

\section{TROŠKOVI POPRAVKE I POVLAČENJA AVIONA IZ SAOBRAĆAJA KOJI SU UZROKOVANI UDARIMA PTICA U VETROBRAN}

\section{REZIME}

Prema dostupnim podacima koje je objavila Evropska agencija za bezbednost vazdušnog saobraćaja (EASA) u periodu od 1990. do 2007. godine na teritoriji Sjedinjenih Američkih Država, Ujedinjenog Kraljevstva i Kanade desilo se više od 94743 sudara vazuhoplova sa pticama. U nekim delovima sveta populacija ptica značajno raste. Takođe, broj vazduhoplovnih operacija raste $u$ poslednjim decenijama, i što je još važnije, dalji rast se očekuje $i$ u budućnosti. U ovakvim uslovima očekuje se i porast broja sudara vazduhoplova sa pticama. Sudari vazduhoplova sa pticama utiču na bezbednost vazdušnog saobraćaja i generišu dodatne troškove. Rad će prikazati vrste troškova uzrokovane sudarima vazduhoplova s pticama sa akcentom na troškove popravke i povlačenja aviona iz saobraćaja. Troškovi popravke i povlačenja aviona iz saobraćaja usled sudara sa pticama su specifični jer variraju od zanemarljivih do višemilionskih novčanih iznosa, osim toga specifičnost pomenutih događaja se ogleda i u njihovoj nepredvidivosti.

\section{KLUUČNE REČI}

sudar vazduhoplova sa pticama; bezbednost; troškovi popravke; povlačenje aviona iz saobraćaja;

\section{REFERENCES}

[1] FAA. Wildlife Strikes to civil aircraft in the United States 1990-2013, Serial report number: 20; 2014.

[2] Steiner S, Galović B, Radačić Ž. Strategic Framework of Air Traffic Development. Promet - Traffic \& Transportation. 2008;20(3): 157-167.

[3] ICAO. Fifteen years of data collection by the ICAO Bird strike information system, Bird Strike Committee Europe, London; 1996.

[4] EASA. Bird population trends and their impact on 
Aviation safety 1999-2008, Safety Analysis and Research Department Executive Directorate; 2009.

[5] Dukiya JJ, Gahlot V. An Evaluation of the Effect of Bird Strikes on Flight Safety Operations at International Airport. International Journal for Traffic \& Transport Engineering. 2013;3(1): 16-33. Available from: http://dx.doi.org/10.7708/ijtte.2013.3(1).02 [Accessed 18 ${ }^{\text {th }}$ May 2017]

[6] Nicholson R, Reed W. Strategies for Prevention of bird-strike events. Aeromagazine. 2011;11(3): 16-24. Available from: http://www.boeing.com/commercial/ aeromagazine/articles/2011_q3/pdfs/AERO_2011_ Q3_article4.pdf [Accessed $8^{\text {th }}$ Sep 2017]

[7] ICAO. International Civil Aviation Organization. Electronic Bulletin 2001 - 2007 Bird Strike Analyses IBIS; 2009.

[8] Allan J. The costs of bird strikes and bird strike prevention, USDA National Wildlife Research Cener Symposia; 2000.

[9] FAA. Wildlife Strikes to civil aircraft in the United States1990-2008, Serial report number: 15; 2009.

[10] CODA. Delays to Air Transport in Europe. DIGEST Annual 2008. EUROCONTROL, Brussels, Belgium; 2009.

[11] ITA (Institut du Transport Aérien, Paris). Costs of Air Transport delay in Europe; 2000.

[12] Ball M, Barnhart C, Dresner M, Hansen M, Neels K, Odoni A, Peterson E, Sherry L, Trani AA, Zou B. Total delay impact study: a comprehensive assessment of the costs and impacts of flight delay in the United States. National Center of Excellence for Aviation Research; 2010.

[13] FAA. Wildlife Strikes to civil aircraft in the United States 1990-2014. Serial report number: 21; 2015.

[14] Boeing. A Discussion of the Capacity Supply - Demand Balance within the Global Commercial Air Transport Industry. Aviation System Analysis, Boeing Commercial Airplanes; 2013.

[15] FAA. Economic values for FAA investment and regulatory decisions, Section 4: Aircraft operating costs; 2016.

[16] Čokorilo O, Gvozdenović S, Mirosavljević P, Babačev N. The Impact of aircraft incident on the unit operating costs of civil aircraft. Proceedings of the $12^{\text {th }}$ World Conference on transport research (WCTRS), 11-15 July 2010, Lisbon, Portugal; 2010. p. 1-6.

[17] Čokorilo O, De Luca M, Dell'Acqua G. Aircraft safety analysis using clustering algorithms. Journal of Risk Research. 2014;17(10): 1325-1340.

[18] Nešić A, Čokorilo O, Steiner S. Modeling the costs of the bird strikes prevention. Proceedings of the $3^{\text {rd }}$ International Conference on Traffic and Transport Engineering (ICTTE), 24-25 November 2016, Belgrade, Serbia; 2016. p. 36-43. Available from: http://ijtte. com/uploads/news_files/ICTTE\%20Belgrade $\% 20$ 2016_Proceedings.pdf [Accessed 15th Sep 2017] 